\begin{tabular}{l}
\hline OPEN O ACCESS Freely available online \\
http://www.banglajol.info/index.php/BJID/index \\
Original Article \\
Bangladesh Journal of Infectious Diseases \\
October 2020, Volume 7, Number Suppl_2, Page S8-S15 \\
ISSN (Online) 2411-670X \\
ISSN (Print) 2411-4820 DOI: https://doi.org/10.3329/bjid.v7i00.50156
\end{tabular}

\title{
Impact of COVID-19 Pandemic among Health Care Providers in Bangladesh: A Systematic Review
}

\author{
Md. Jamal Hossain
}

Department of Pharmaceutical Chemistry, Faculty of Pharmacy, University of Dhaka, Dhaka-1000, Bangladesh; Email: jamal.du.p48@gmail.com; Cell no.: +88 01517814866

[Received: 17 August 2020; Accepted: 28 September 2020]

\begin{abstract}
Background: The world has been passing the most critical time of the century with the COVID-19 pandemic since late December 2019, and numerous people, including a significant portion of health care providers, got the infection and are still sacrificing their lives. Objective: The study was aimed systematically to assess the severity of the SARS-CoV-2 infection, especially in health care sectors, and to appraise the physical, psychological, and social effects of the COVID-19 epidemic among frontline fighters in Bangladesh. Methodology: The keywords: "COVID-19", "SARS-CoV-2", "health care system in Bangladesh", "health care providers", etc. were searched to collect the desired articles by utilizing various search engines like google, google scholar, pub med, and science direct journals. Data were extracted and finally, were summarized, discussed, analysed, and reported the study results. Result: Numerous specialist doctors, nurses, and all other healthcare workers are immolating their lives to save human entities amid the current coronavirus pandemic, 2019 (COVID-19). In Bangladesh, till August 9, 2020, 73 doctors, including some senior specialists, died of COVID-19 infection reported by various national newspapers. At the early phase of this epidemic in Bangladesh, around $10 \%$ of the total infection was found among health workers, alarmingly reported by the Bangladesh Medical Association (BMA). These frontline fighters are additionally confronting numerous challenges, including psychological sufferings, and furthermore, they are assaulted by the society. Conclusion: Since these fighters are relinquishing their beloved lives to protect us from this brutal virus, we are trying to show our profound gratitude, appreciation, thousands of salutes, and undying tribute to these health care fighters with this publication. [Bangladesh Journal of Infectious Diseases, October 2020;7(suppl_2):S8-S15]
\end{abstract}

Keywords: Bangladesh; SARS-CoV-2; COVID-19; frontline fighters; undying tribute; psychological support

Correspondence: Md. Jamal Hossain, Department of Pharmaceutical Chemistry, Faculty of Pharmacy, University of Dhaka, Dhaka-1000, Bangladesh; Cell no.: +88 01517814866; Fax: +88-02-9667222; Email: jamal.du.p48@ gmail.com; ORCID iD: https://orcid.org/0000-0001-9706-207X

Conflict of interest: The author has no conflicts of interest to declare.

Funding agency: The author did not receive any type of funding for this study.

Contribution to authors: Hossain MJ involved in protocol preparation, data collection and literature search up to manuscript writing as well as revision of this manuscript.

How to cite this article: Hossain MJ. Impact of COVID-19 Pandemic among Health Care Providers in Bangladesh: A Systematic Review. Bangladesh J Infect Dis 2020;7(suppl_2):S8-S15

Copyright: @2020. Hossain. Published by Bangladesh Journal of Infectious Diseases. This article is published under the Creative Commons CC BY-NC License (https://creativecommons.org/licenses/by-nc/4.0/). This license permits use, distribution and reproduction in any medium, provided the original work is properly cited, and is not used for commercial purposes. 


\section{Introduction}

A quick transmissible global health solicitous, the coronavirus disease 2019 (COVID-19) is an infection caused by the mysterious and contagious novel severe acute respiratory syndrome virus-2, SARS-CoV-2 ${ }^{1,2}$. The World Health Organization (WHO) has addressed this fresh viral infectious disease as a pandemic threat authoritatively on 11 March $2020^{3}$. Bangladesh, the $8^{\text {th }}$ most crowded country, is one of the third world countries in the world. The World Population Review 2020 has estimated its population size around 164 million, of which 2.4 million live abroad, and the male to female ratio has been reported to be 100.2:100. The Director of the Institute of Epidemiology, Disease Control and Research (IEDCR), Dhaka, Bangladesh, has admonished about the risk situation of Bangladesh on 4 March 2020. As Bangladesh has significant connectivity and network with the countries where the infection rate is quite high, it is presently at a high risk of being contaminated by the imported virus anytime 4 . However, Dhaka, the capital city of Bangladesh, has recorded its first three coronavirus infected patients on 8 March 2020; two of the patients were returnees from Italy 5 .

According to woldometer data, on 18 September 2020, the number of SARS-CoV-2 infected people globally was around 30 million, and more than 952 thousand patients lost their lives. Up to the same date, more than 345 thousand Bangladeshi populations have been infected, and 4,881 people died of this pandemic. Meanwhile, the source has additionally stated that 252,335 patients have received the medical certificate as they recovered from COVID-19.

As this infectious disease does not have any vaccines or medications, it must be controlled by slowing down its transmission, and our foremost aim is to lower the mortality rate of the infected patients. In this battle, our frontline warriors are doctors, nurses, pharmacists, health workers, law enforcement agencies, and others who have been fighting against COVID-19 nationally as well as globally. Unfortunately, our frontline fighters have been getting the SARS-CoV-2 infection at a high rate since the embryonic stage of the pandemic, and many daily and international reports expressed their concerns as Bangladesh were losing plenty of doctors and other health workers. In Bangladesh, till 9 August, 2020, 2531 doctors, 1754 nurses, and 3011 health workers have been got SARS-CoV-2 infection, and 73 specialist doctors died of this COVID-19 disease ${ }^{6}$.
This research has defined the actual catastrophic graphical picture of the COVID-19 outbreak and further illuminated the human service of the medical workers despite the inadequate health infrastructure in Bangladesh. The goal of the study is to express our tribute and infinite esteem to these respectable frontline fighters during this COVID-19 outbreak. To achieve success, our health caretakers and specialists must keep fighting the virus. They have sacrificed their valuable lives to save us from this notorious virus. This publication has shown millions of special salutes and deep homage towards these valorous frontline fighters. This article also suggests ensuring compulsory psychological help for these fighters and remaining beside them during this pandemic.

\section{Methodology}

Study design: Firstly, I selected the clear objective and search strategies, and identified and collected the relevant articles. Secondly, I picked out the research articles to be discussed in a systematic way. Thirdly, I extracted and made charts of the available data, and finally, I summarized, discussed, analyzed, and reported the results of the study.

Search and data collection: I searched articles on Google, Google Scholar, Pub Med, Science Direct, and used some other National Journals, including some Bangladeshi daily paper articles, to collect data regarding the health system of Bangladesh and the contribution and conditions of the stated frontline health care fighters. Many national newspapers and the website of IEDCR, Health Ministry, odometer, Wikipedia, Corona Tracker, etc. have been utilized for searching and collecting COVID-19 updates regarding daily infection, mortality, recovery, and number of the SARS-CoV2 tests in Bangladesh.

Data extraction, selection, and illustration: I narrowed the search down to the most relevant and appropriate articles for this study. I used data scrutinizing and a systematic logical way for information extraction, as well as considered some editorial letters and comments. Data distinguishing proof, screening, eligibility checking, and inclusion steps have been included for the strategy segment. Graphical illustrations are presented in this paper according to the COVID-19 updates from 8 March 2020 to 18 September 2020.

\section{Results}

\section{Destitute testing facility}

The actual situation of COVID-19 can be understood from the number of tests in the country. 
Figures I (A and B) presented the daily testing number and the percentage of infection in Bangladesh. Despite the low testing number in the country, the infection is significant. It is fortunate that Bangladesh's testing rate per million people is 4,343 , which is, as reported by the worldometer, higher than Myanmar and a low-income country, Afghanistan. However, the number is much lower than its other neighboring countries (Figure II). The poor diagnostic testing facility in Bangladesh is the basic and triggering point that geared up these awful situations among the mass populations in the country. However, the daily testing numbers were increasing day by day, yet not satisfactorily. The district-wise distribution of COVID-19 infections in the country illustrated the rapid transmission of this virus throughout the country before 30 May 2020 . The highest infection rate of health care workers was alarmingly reported in the Dhaka district (Figure III).
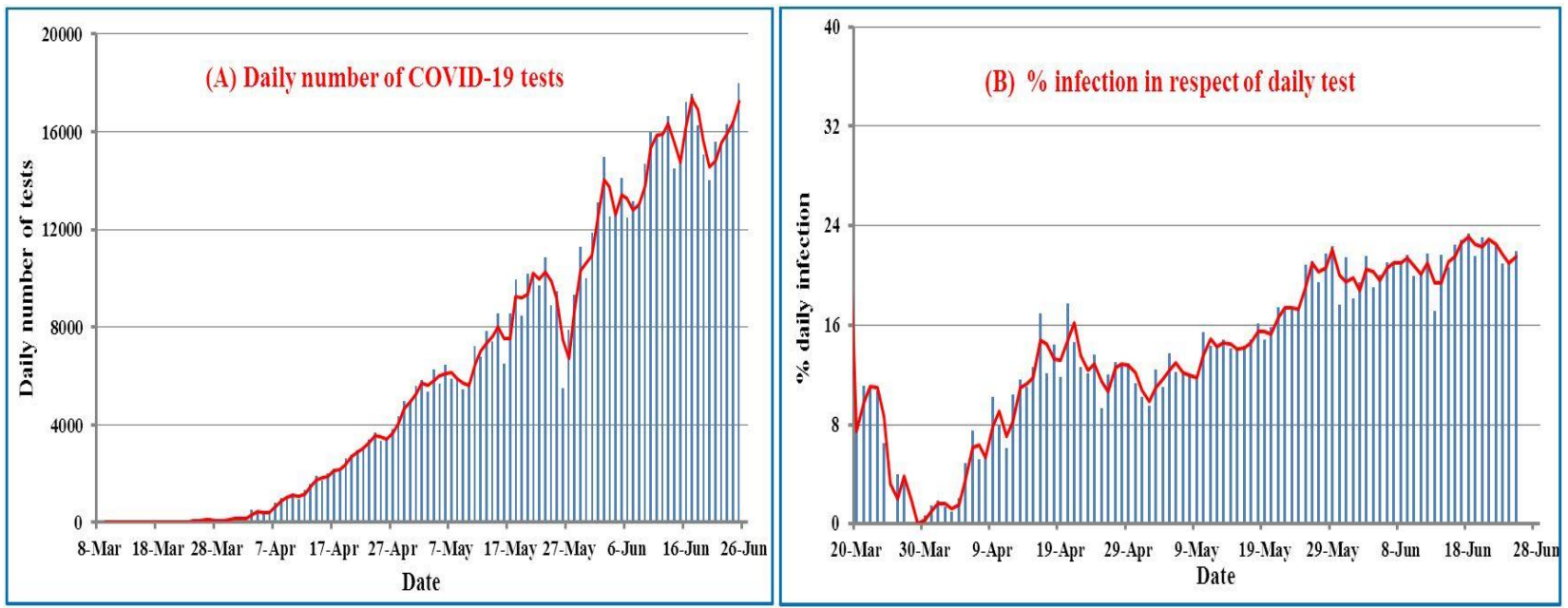

Figure I: (A) Number of daily COVID tests and (B) percentage of infected patients with respect to daily tests

\section{Doctors, nurses, and health workers as 'frontline warriors'}

Physicians, medical attendants, pathologists, therapeutic staff, and all kinds of health workers must play a leading part in winning this corona pandemic war. The developed countries are confronting a crisis to fight the COVID-19 global outbreak, and Bangladesh has a weaker health system than others. However, Bangladesh is fighting hard to come back from this anathema. The contributions of health workers, especially doctors and nurses, have been recognized by everyone. The WHO has already declared nurses as heroes for their brave performance in this pandemic.

Despite the lack of a proper health care framework in Bangladesh, such as mandatory precautionary equipment, these health care workers are serving the people day and night at a high risk of their lives. The number of doctors, nurses, and medical staff infected with COVID-19 is quite high in Bangladesh. The treatment of coronavirus cannot be expected from such a vulnerable and high-risk medical system. Concurring with the Bangladesh Medical Association (BMA), 11\% of total infected cases in Bangladesh have been detailed for health care workers till the last week of April $2020^{7}$ and till 9 August 2020, seventy-three doctors, including some senior specialists, lost their lives ${ }^{6}$.

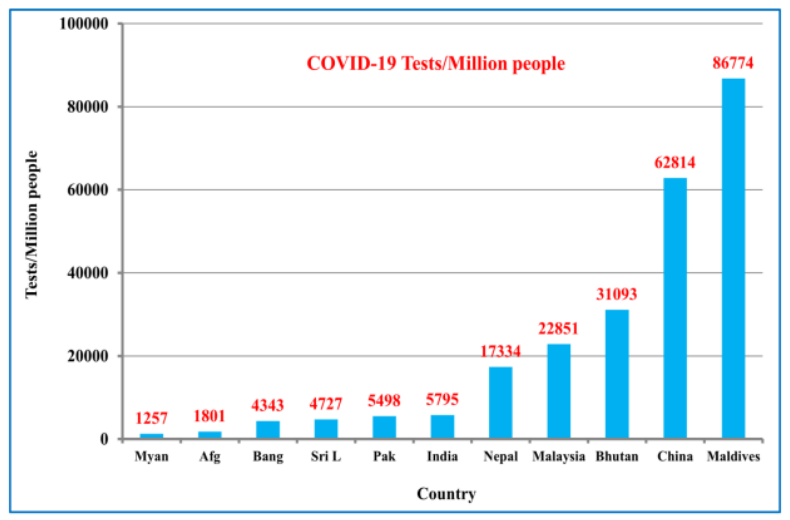

Figure II: Number of tests per million people in Bangladesh in comparison with its neighboring countries up to 27 June 2020. (Data: https://www.worldometers. info/coronavirus/) 


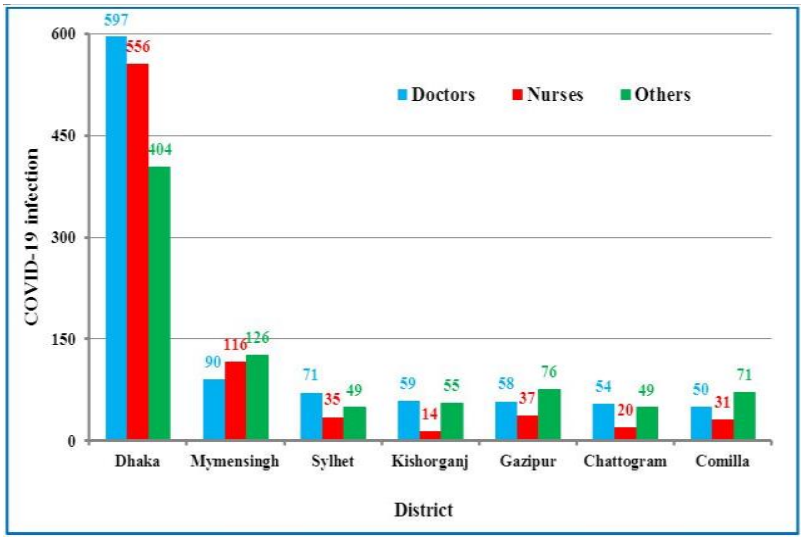

Figure III: Most seven districts of COVID-19 infected doctors, nurses, and other healthcare professionals in Bangladesh up to 26 June 2020. (Data: BMA; https://bma.org.bd/).

It is redundant to set forth explicitly; the doctors, as well as all health workers, have been fighting COVID-19 to come back from its inception phase in Bangladesh. Without any conservation and suspicion, they are trying their best to help as the frontline fighters in this imperceptible battle. Due to the inability to take consult from doctors physically, another beacon of hope for people is the "Telemedicine" service through electronic technology as hundreds of millions of inhabitants are staying at home amidst this epidemic. Many public and private organizations have been trying to provide this imperative service to quench the lacunae between doctors and patients in this current pandemic ${ }^{8}$. Moreover, many groups or pages in social media have been functioning to boost the basic health care services provided by many doctors and specialists.

\section{Allegations and Special Incentives}

In the early phase of this outbreak, there were some allegations against doctors and hospitals for dreading to treat patients with coronavirus symptoms, as the doctors needed personal protective equipment, proper training, and other treatment facilities for suspected patients ${ }^{9}$. Indeed, the specialists or nurses were not affirmed as the patients were COVID-19 positive or negative due to a lack of testing. With time, the scenario has changed as the doctors began to play their correspondence role as soldiers against this new threat.

To promote doctors, nurses, and other health workers who are working for battling this pandemic, the prime minister of Bangladesh has pronounced health insurance and special incentives for them ${ }^{10}$. Two thousand doctors and six thousand nurses were recruited freshly during this pandemic to enrich the wellbeing framework, and it has been working effectively in this COVID-19 situation ${ }^{11}$.

\section{Negative attitudes toward coronavirus infected patients, doctors, and volunteers}

A distinctive emergency has arisen in the health care system in Bangladesh concerning doctors and health workers related to COVID-19 treatment. Infected patients, their family members, medical workers, and doctors are found to be socially confined. It is imperative to bear in mind that the frontline warriors against COVID-19, especially doctors and nurses, are being eulogized globally. In contrast, the illustration in Bangladesh is conflicting in numerous cases. They are facing many challenges, such as threatening or informal comments by their proprietors and society individuals from the initial stage of this outbreak. Due to this, all health care workers in Bangladesh are getting disappointed. All corona fighters are being felicitated abroad, whereas they are shunned in their country. This sort of frustration will demotivate these cutting-edge soldiers on the battle.

It is pathetic that infected people and their family members were treated inhumanly by society instead of support both mentally or logistically. In some cases, it has been reported that the villagers had hindered during the funeral time of the dead body. This type of exercise has happened due to the lack of accurate knowledge about COVID-19 and the fear of the pandemic, which is a menace for mental health. Another matter of concern is that some COVID-19 positive patients flee from the hospitals with symptoms due to negative attitudes toward this novel virus, which may further mystify the current situation in Bangladesh.

\section{Stigma as 'super spreader'}

Physicians, nurses, and health workers, who are engaged with COVID-19 work, have been hated, assaulted, and obstructed as well as addressed as the carrier of this virus, which has been published in numerous reports ${ }^{12}$. As the infection rate among doctors and nurses was rising at an outrageous pace, these fear and damnation surged throughout the country $^{13}$. Other than this dishonor, these medical workers face mental confusion, fast infection risk, insufficient self-protection, extra duty, and negative attitudes that result in mental stress, fear, anger, insomnia, depression, and anxiety, including other psychological disorders ${ }^{14,15}$. 


\section{Pharmacists as the 'silent fighters'}

The role of pharmacists in the health sector is essential universally. To enhance the safe and judicious use of drugs or vaccines as well as maintain pharmacokinetic parameters through patient monitoring for any disorders, including any pandemic such as COVID-19, clinical pharmacists are required in hospitals and specialized clinics.

During this global crisis, pharmacists are not sitting in their home rather they are working hard to supply the required life-saving medications at high risk. Government pharmaceutical companies deliver free medications to people through public hospitals and clinics in Bangladesh. Currently, 100\% of essential drugs and $98 \%$ of all local demanded medications have been met by the Bangladeshi pharmaceutical sector $^{16}$. It is a jovial matter that Bangladesh exports to more than 145 countries while maintaining the best quality ${ }^{17}$.

These drug specialists are adorned with sufficient skill, knowledge, and attitudes regarding drug preparation to safe dispensing. Hospital pharmacists play a role in the proper formulation, compounding, and safe storage of drugs, whereas clinical pharmacists efficiently ensure the rational use of drugs (RUD) after prescription.

Additionally, to ascertain proper care in a community-based health system, community pharmacists are the pylon in this regard ${ }^{18}$. The WHO has recommended that there must be one physician and one pharmacist for every thousand people. However, there has been no recruitment of graduate clinical pharmacists in government hospitals in Bangladesh, whereas private organizations have been enlisting them to work in the existing health facilities ${ }^{19}$.

Playing a role in controlling the infection, including supporting patient care along with hospital pharmacists, community pharmacists are also excellent health care providers as they stay on the front line of the Public Health Service during this COVID-19 pandemic ${ }^{20}$.

In this critical time, pharmacists are forcing continuously to keep up the preparation and supply drugs to meet the demand of the nation at high risk. They should be respected and their safety needs to be ensured, including financial support, as they are also silent frontline fighters in this invisible war.
Law enforcement agencies and others as 'outdoor fighters'

Moreover, health care workers and law enforcers like police and army, including all administrative officials, are not under house arrest at present. Instead, they help keep the unruly populaces home, enforce government orders, and fine-tuning the bigots. They are putting extreme effort to ensure social distancing in the busy streets of the cities risking the infection. The Bangladesh Police Headquarters stated that nearly 10,000 cops were infected, and thirty-eight died of this virus till 26 June 2020 while performing the duty amid this epidemic in Bangladesh ${ }^{21}$. Journalists and media are also working hard to provide proper updates without hesitation. Bankers, food suppliers, electric service members, volunteers, and all other frontline fighters are putting their safety at risk to execute their duties in this pandemic time.

\section{Discussion}

\section{Health Care Infrastructure in Bangladesh: Triumph and Stigma}

Government, non-government, and private institutions have been providing support to ascertain legitimate health services for every citizen in Bangladesh. After the inception of the country from the liberation war of 1971, despite its pervasive poverty, it has been applauded for perpetrating a lot of impressive progress by a surprisingly exceptional rate both in the medical and pharmaceutical sectors $^{22-24}$. The health care quality and access (HAQ) index have increased from 47.0 to 61.1 in the period from 1990 to 2015, which was better than that of some of its neighboring countries ${ }^{25}$. It has introduced itself through the globe as an exemplar of 'good health at low cost' 26,27 .

Despite these achievements in the health sector, Bangladesh is still enduring an insufficient health budget and a massive lack of health workers ${ }^{28,29}$, which is difficult to tackle during severe health crises like the COVID-19 pandemic. The health sector budget of the fiscal year 2019-2020 was $5.63 \%$ (proposed) of total allocation by the finance minister ${ }^{30}$, whereas doctors and civil society demanded $12 \%$ of the total for health allocation ${ }^{31}$. Another incredible stigma for this health sector is that overall, $67 \%$ of medical costs must be paid by patients, and 34\% vacancy can't be recruited due to scarcity of allocation ${ }^{32}$. The current doctor-patient and nurses-patient ratios are only 5.26 and 3.06, respectively, in Bangladesh, which is lower than in 
other South Asian countries except for Bhutan and Afghanistan ${ }^{33}$.

\section{Pictorial illustration of the COVID-19 catastrophe in Bangladesh:}

As Bangladesh became the first to experience COVID-19 positive patients earlier in March 2020 and was almost 2.5 months after the Wuhan infection, the country functioned the normal deeds without any difficulty until late March 2020. The infection rate was negligible until the mid of April, but the rate increased exponentially since May. To reach 20,000 total infected patients in Bangladesh, it took 69 days from its first infection date (8 March to 15 May 2020; Figure IV A); unfortunately, it took only 12 days to double the number of infected people. It is the most difficult situation because, currently, there are more than 3,000 infections per day, whereas it was below 600 at the start of May (Figure IV B). Therefore, the last two months (May and June) saw the catastrophic growth of COVID19. It is fortunate for Bangladesh that till now, we have not lost many lives compared to other parts of the world, which is evident from Figures IV C and IV D. It is also promising that the recovery rate has increased tremendously, starting from May (Figures IV $\mathrm{E}$ and IV F).
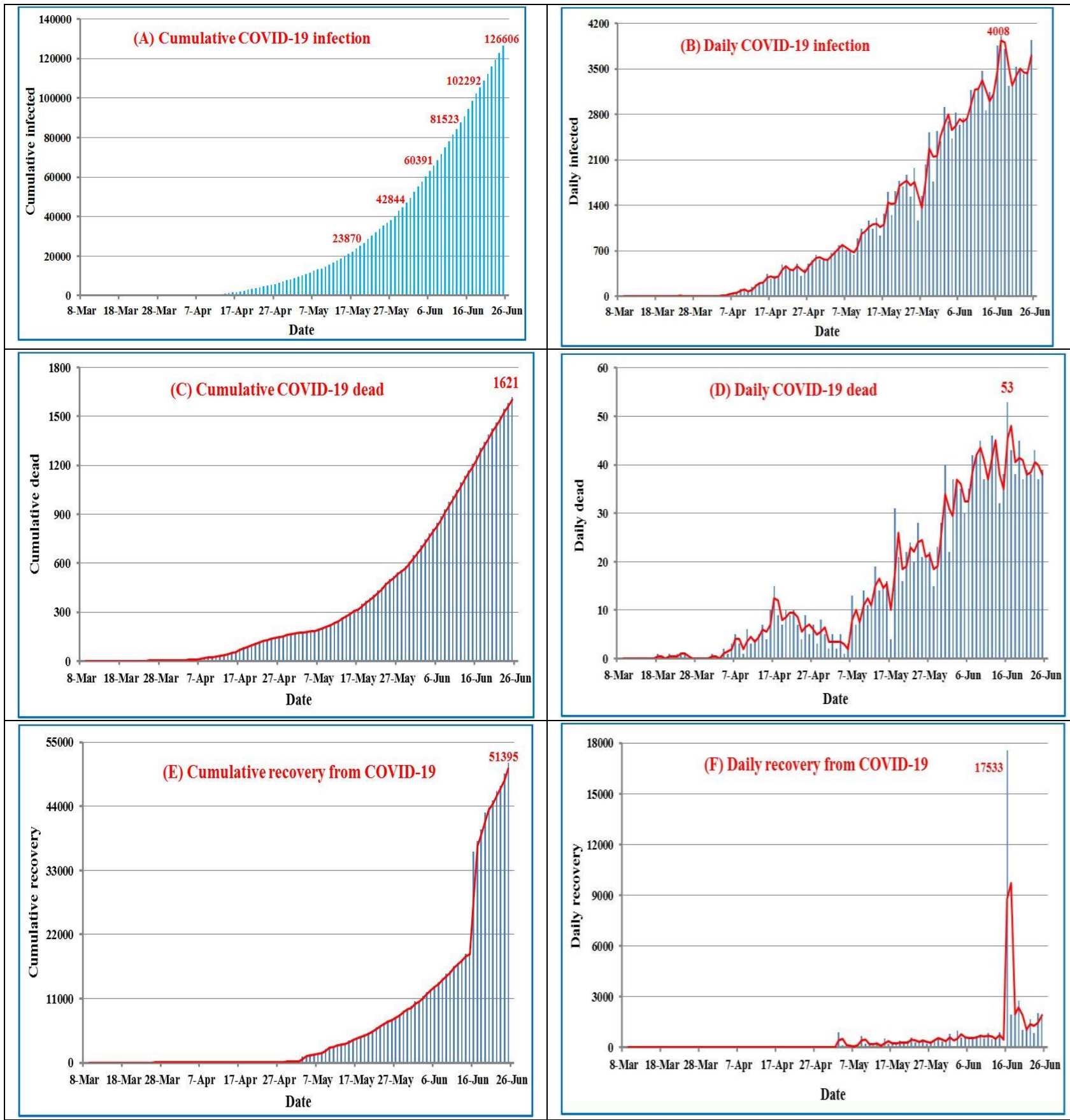

Figure IV: COVID-19 pandemic situation up to date (25 June 2020) in Bangladesh. (A) Cumulative number of infected patients, (B) daily identified, (C) cumulative death, (D) daily death, (E) cumulative recovery, and (F) daily recovery number of patients in Bangladesh from 8 March to 25 June 2020 (Data source: IEDCR, Corona Tracker, and Wikipedia) 
As the number of infected patients is surging upward in hospitals exponentially rate in Bangladesh, health care providers must overwork to handle gaggling patients. The augmented number of patients is surcharging several physical and psychological disorders to the frontline warriors. Thus, health authorities and policy creators must accentuate the collaborative efforts not only to ensure corporal care but also to ensure psychological stability for all the workers, who are at the highest risk of infection. Bangladeshi health workers are playing a leading role in winning this battle against this novel coronavirus. They are highly loyal, sincere, and committed so that no patient will return home without treatment in these troubling times.

\section{Conclusion}

In conclusion, all Bangladeshi and global physicians, nurses, pharmacists, health technologists, and frontline fighters of COVID-19 must be worthy of getting the utmost honor, tribute, and applauds. More importantly, Bangladeshi COVID-19 warriors are fighting with full heart despite lacking proper health infrastructure and lower socioeconomic status.

They furthermore deserve thousands of special salutes, unending respect, and abundant blessings without any controversy. Besides, this article recommends ensconcing the required psychological support for these health care workers and staying beside them during this epidemic.

\section{References}

1. Mao R, Liang J, Shen J, Ghosh S, Zhu LR, Yang,H, et al. Implications of COVID-19 for patients with preexisting digestive diseases. Lancet Gastroenterol Hepatol 2020;5:425-7.

2. Chen Y, Guo Y, Pan Y, Zhao ZJ. Structure analysis of the receptor binding of 2019-nCoV. Biochem. Biophys Res Commun 2020;525:135-40.

3. WHO. Coronavirus disease 2019 (COVID-19) situation report 51 [cited Mar 11, 2020]. Available form: https://www.who.int/docs/default-

source/coronaviruse/situation-reports/20200311-sitrep51-covid-19.pdf?sfvrsn=1ba62e57 10.

4. New Age. Bangladesh at high risk of coronavirus. [cited Mar 5, 2020]. Available from: https://www.newagebd.net/article/101292/bangladesh-at- high-risk-of-coronavirus

5. The Daily Star. First coronavirus cases confirmed. [cited Mar 9, 2020]. Available from: https://www.thedailystar.net/frontpage/news/firstcoronavirus-cases-confirmed-1878160.

6 . The business standard. So far 73 doctors die of Covid19 in Bangladesh. [cited Aug 9, 2020]. Available from: https://tbsnews.net/coronavirus-chronicle/covid-19bangladesh/so-far-73-doctors-die-covid-19-bangladesh117301.

7. Dhaka Tribune. BMA: Healthcare workers account for $11 \%$ of COVID-19 cases. [cited April 27, 2020]. Available

from:

https://www.dhakatribune.com/health/coronavirus/2020/ 04/27/healthcare-workers-account-for-11-of-covid-19cases-bma.

8. UNB News. Telemedicine: A ray of hope for people amid pandemic. [cited April 30, 2020]. Available from: https://unb.com.bd/category/Special/telemedicine-a-rayof-hope-for-people-amid-pandemic/50831.

9. New Age. Patients suffer as hospitals limit services. [cited April 2, 2020]. Available from: https://www.newagebd.net/article/103621/patientssuffer-as-hospitals-limit-services.

10. The Business Standard. PM anounces special insurance, stimulus for COVID-19 frontline fighters. [cited April 7, 2020]. Available from: https://tbsnews.net/coronavirus-chronicle/covid-19bangladesh/pm-holding-videoconference-coronavirussituation-66124.

11. The Business Standard. Coronavirus: Govt to recruit 2,000 doctors , 6,000 nurses within a week. [cited April 23, 2020]. Available from: https://tbsnews.net/bangladesh/health/govt-recruit-2000doctors-and-6000-nurses-72910.

12. The Business Standard. Fear, hatred and stigmatization grip Bangladesh amid COVID-19 outbreak. [cited Mar 26, 2020]. Available from: https://tbsnews.net/thoughts/fear-hatred-and-

stigmatization-grip-bangladesh-amid-covid-19-outbreak$\underline{61129 .}$.

13. Dhaka Tribune. Coronavirus: Frontline warriors at risk of becoming "super spreaders". [cited April 27, 2020]. Available from: https://www.dhakatribune.com/health/coronavirus/2020/ 04/21/covid-19-frontline-warriors-at-risk-of-becomingsuper-spreaders.

14. Kang L, Li Y, Hu S, Chen M, Yang C, Yang BX, et al. The mental health of medical workers in Wuhan, China dealing with the 2019 novel coronavirus. Lancet Psychiatry 2020;7:e14

15. Xiong Y, Peng L. Focusing on health-care providers' experiences in the COVID-19 crisis. Lancet Glob Health 2020;8:e740-e741

16. Dhaka Tribune. Bangladesh pharmaceutical industry blooms bigger. [cited Aug 22, 2019]. Available from: https://www.dhakatribune.com/business/2019/08/22/ban gladesh-pharmaceutical-industry-blooms-bigger.

17. The Financial Express. Pharmaceutical sector flourishing. [cited Nov 27, 2020]. Available from: 
https://www.thefinancialexpress.com.bd/views/pharmace utical-sector-flourishing-1574867109.

18. Malik I, Atif M. Global menace of superbugs: Time to consider a "Pharmacist led one health approach" to counteract the crisis. Res Social Adm Pharm 2020;16:848-9.

19. Dhaka Tribune. No pharmacists in govt hospitals. [cited May 14, 2020]. Available from: https://www.dhakatribune.com/health/coronavirus/2020/ 05/14/no-pharmacists-in-govt-hospitals.

20. Bukhari N, Rasheed H, Nayyer B, Babar ZU. Pharmacists at the frontline beating the COVID-19 pandemic. J Pharm Policy Pract 2020;13:8

21. The Daily Star. Bangladesh police staffer dies from COVID-19. [cited June 27, 2020]. Available from: https://www.thedailystar.net/country/news/bangladeshpolice-staffer-dies-covid-19-1921325.

22. Hossain R. Current status of health sector in Bangladesh. Bangladesh Med J 2015;44:46-50.

23. Chowdhury AMR, Bhuiya A, Chowdhury ME, Rasheed S, Hussain Z, Chen LC. The Bangladesh paradox: exceptional health achievement despite economic poverty. Lancet 2013;382:1734-45.

24. Arifeen SEI, Christo A, Reichenbach L, Osman FA, Azad K, Islam KS, et al. Community-based approaches and partnerships: innovations in health-service delivery in Bangladesh. Lancet 2013;382:2012-26.

25. Barber RM, Fullman N, Sorensen RJD, Bollyky T, McKee M, Nolte E, et al. Healthcare access and quality index based on mortality from causes amenable to personal health care in 195 countries and territories, 1990 - 2015: a novel analysis from the Global Burden of Disease Study 2015. Lancet 2017;390:231-66.

26. Adams AM, Ahmed SM, Evans TG. Universal health care in Bangladesh - promises and perils. Lancet Glob Health 2018;6:e10-e11

27. Balabnova D, Mills A, Conteh L, Akkazieva A, Banteyerga H, Dash U, et al. 2013. Good health at low cost 25 years on: lessons for the future of health systems strengthenin. Lancet 381:2118-33.

28. Hassan MZ, Fahim SM, Zafr AHA, Islam MS, Alam S. Healthcare financing in Bangladesh: challenges and recommendations. Bangladesh J Med Sci 2016;15:50510.

29. Islam MR, Rahman MS, Islam Z, Nurs CZB, Sultana $\mathrm{P}$, Rahman MM. Inequalities in financial risk protection in Bangladesh: an assessment of universal health coverage. Int J Equity Health 2017;16:59

30. New Age. Health sector allocation goes up. [cited Jun 13, 2019]. Available: https://www.newagebd.net/article/75202/health-sectorallocation-goes-up.

31. Dhaka Tribune. Doctors demand $12 \%$ of budget be allocated for health sector. [Cited Jun 19, 2019]. Available from: https://www.newagebd.net/article/75202/health-sectorallocation-goes-up.

32. Fahim SM, Bhuayan TA, Hassan MZ, Zafr AHA, Begum F, Rahman MM, et al. Financing health care in Bangladesh: Policy responses and challenges towards achieving universal health coverage. Int J Health Plann Manage 2019;34:e11-e20

33. Dhaka Tribune. Patients, doctors, nurses ratio: Bangladesh lags far behind its neighbours. [cited Jul 21, 2019]. Available from: https://www.dhakatribune.com/health/2019/07/21/patient -doctors-nurses-ratio-bangladesh-lags-far-behind-itsneighbours. 